\title{
SERUM VISFATIN LEVEL IN RELATION TO THE SEVERITY OF CORONARY ARTERY DISEASE
}

\author{
By
}

\section{Ayman Mohamed Salem ${ }^{1}$, Abdullah Hussein El-Sadek ${ }^{1}$, Mohammed Noshy El-Alfy ${ }^{1}$, Mansour Mohammed Mustafa ${ }^{2}$ and Kamel Soliman Hammad $^{3}$}

Departments of Internal Medicine1, Cardiology2 and Clinical Pathology3, Faculty of Medicine, Al-Azhar University, Cairo, Egypt

E-mail: ayman.nafie@yahoo.com

\begin{abstract}
Background: Visfatin is a novel adipocytokine which mainly found in visceral adipose tissue. Visfatin may be related to endothelial function, which is indispensable for coronary circulation, and may be an indicator of an inflammatory event in the coronary arteries.
\end{abstract}

Objective: To evaluate the severity of Coronary Artery Disease in relation to serum visfatin level.

Patients and Methods: This was a case-control study done at Bab El-Sharia University Hospital, Al-Azhar University, arranged to conduct 90 Egyptian patients underwent elective coronary angiography for suspected CAD. Patients were divided into 60 patients with CAD (patients group), and 30 patients with normal coronary angiography (control group).The severity of CAD was assessed using coronary angiography by estimating the number of vessels affected. Patients with CAD were divided equally to: diabetic patients with coronary artery disease and non-diabetic patients with coronary artery disease.

Results: Visfatin was higher in patients group in comparison to control group; it was $16.68 \pm 4.67$ and $2.95 \pm$ 0.87 respectively, and it was clear that the serum level of visfatin was significantly higher in groups with more vessels involvement. As the Mean \pm SD of visfatin in one vessel group was $13.13 \pm 2.77$ and was 16.95 \pm 2.89 and $21.99 \pm 3.91$ in two vessels and three vessels respectively. In comparison between diabetic and non-diabetic patients, visfatin was significantly higher in diabetic patients with coronary disease artery disease (Mean \pm SD: $18.97 \pm 4.54$ ) than non-diabetic patients with coronary artery (Mean \pm SD: $14.39 \pm$ 3.59).

Conclusion: Patients with CAD showed increased visfatin serum levels particularly diabetics. Moreover, high visfatin levels were significantly correlated with CAD severity.

Keywords: Visfatin, Coronary Artery Disease.

\section{INTRODUCTION}

Obesity represents a major health challenge it increases the risk of diseases such as type 2 diabetes mellitus, hypertension, and myocardial infarction (Bluher, 2019). Adipose tissue is currently considered not only a storage tissue but rather an endocrine organ, modulating several physiological functions (including glucose and lipid metabolism, thermogenesis, neuroendocrine function, blood pressure, and immunity) through the release of mediators usually termed as adipocytokines (Carbone et al., 2015).

An estimation of visceral adipose tissue is important. Epicardial adipose tissue (EAT) is part of the visceral adipose tissue that surrounds the heart and it is a 
quantifiable, modifiable, and multifaceted tissue that has both local and systemic effects. When EAT is enlarged, EAT contributes to atherosclerotic cardiovascular risk and plays a role in the development of metabolic syndrome (Villasante and Iacobellis, 2019). EAT is a rich source of free fatty acids and is capable of secreting proinflammatory and proatherogenic cytokines as well as antiatherogenic adipocytokines

(Bornachea et al., 2018).

Various pro- and anti-inflammatory mediators and cytokines are secreted from adipose tissue are collectively called adipocytokines. It has been demonstrated that adipocytokines regulate different stages of atherosclerosis, from endothelial dysfunction to plaque destabilization and rupture (Mazaherioun et al., 2012).

Visfatin is a multifaceted protein that plays an important role in regulating a variety of physiological and pathological processes, including obesity, diabetes and cardiovascular disease (Zheng et al., 2019). It may be related to endothelial function, which is indispensable for coronary circulation, and may be an indicator of an inflammatory event in the coronary arteries (Ucgun et al., 2014). Moreover, Wang et al. (2012) reported that, visfatin participates in several pathophysiological processes contributing to cardio-cerebro-vascular diseases, including hypertension, atherosclerosis, ischemic heart disease.

Although some reported about the relationship of serum visfatin and the risk of CAD, little is known about its relation to the severity of CAD (Mazaherioun et al., 2012).
The present study aimed to evaluate the severity of Coronary Artery Disease in relation to serum visfatin level.

\section{PATIENTS AND METHODS}

The current study was implemented in coordination with the guidelines of the Declaration of Helsinki. Ethical approval was gained according to the recommendations of Ethics Unite, Faculty of Medicine, Al-Azhar University, Cairo, Egypt. The clinical steps and possible adverse events were plainly demonstrated for all candidates. All patients or their legal trustee assigned an informed consent before the enrollment in the study. The study was implemented throughout the period between March 2016 and March 2019 at Bab El-Sharia University Hospital, Al-Azhar University Hospitals.

Ninety patients aged more than 18 years undergone elective coronary angiography for suspected CAD were included in the current study. On the other hand, patients were excluded if they have chronic renal disease, chronic liver disease, history of prior coronary revascularization, patients with pericardial effusion, heart failure or Cardiomyopathy and patients whose transthoracic Echocardiography view was inadequate for measuring EAT thickness. Patients were divided into 60 patients with CAD (patients group), and 30 patients with normal coronary angiography (control group). The severity of CAD was assessed using coronary angiography by estimation the number of vessels affected, and according CAD patients was subclassified according to number of diseased coronary arteries into 1 vessel, 2 vessels and 3 vessels group. 
Then Patients with CAD were divided equally to diabetic patients with coronary artery disease, and non-diabetic patients with coronary artery disease.

All participants were submitted to the following: thorough medical history and physical examination, anthropometric measurement (including height, weight, BMI, and waist circumference), biochemical assays \{including: Glucose concentrations (FBS-2hr PPBS and HbA1c), Insulin levels and HOMA ratio, Lipid profile (Total cholesterol, LDL-C, HDL-C and TG) Urinary albumin excretion ratio and serum visfatin level by Enzyme Linked-Immunosorbent Assay (ELISA)\}.

All patients were examined in the left lateral position by an experienced cardiologist. A Philips ${ }^{\circledR}$ medical ultra sonogram (SONOS 7500, Philips $^{\circledR}$ Medical Systems, USA) with a $3.5 \mathrm{MHz}$ probe was used to obtain transthoracic echocardiography. All measurements were done according to the recommendations of the American Society of Echocardiography.

Epicardial fat thickness measurement: The maximum epicardial fat thickness is measured from a two-dimensional long axis view on the right ventricular free wall parallel to the aortic annulus and in the parasternal short axis view at the tip of the papillary muscle, and then the parasternal long axis and short axis measurements were averaged to obtain the mean thickness. A standard view normally displays the epicardial fat thickness in the right ventricular free wall during normal systolic and diastolic functions, and epicardial fat appears as an echo free space between the outer wall of the right ventricle myocardium and the visceral layer of the pericardium during diastole.

Coronary angiography performed for all patients using a cardiac angiography system (Siemens AG, Medical Solutions, Erlangen, Germany), by the standard Judkin's method, through the femoral artery approach, and at least five projections were performed in all patients to completely expose different segments of coronary artery.

\section{Statistical analysis:}

Continuous-normally distributed variables were reported in the form of mean, and standard deviation (SD), whereby continuous non-normally distributed data were notified using median and range. Besides that, categorical variables were expressed using number, and percentage. Correlation analysis was conducted using Spearman's rank correlation coefficient for categorical data. Mann-Whitney $\mathrm{U}$ test was used to compare the variables. Also, KruskalWallis was used for the three groups. The significance was established when $\mathrm{P}<$ 0.05. Statistical analysis was performed using SPSS software version 23 for Windows (SPSS Inc., Chicago, IL, USA). 


\section{RESULTS}

A total of 90 Egyptian patients underwent elective coronary angiography for suspected CAD. Patients were divided into 60 patients with CAD (patients group) and 30 patients with normal coronary angiography (control group). The age of patients group ranged between $41-70$ with a Mean \pm SD of $(53.75 \pm 6.04)$ of them 40 subjects $(66.7 \%)$ were males \& the remaining 20subjects $(33.3 \%)$ were females. And the age of control group ranged between 39 to 58 years with a Mean \pm SD of $(48.53 \pm 5.02)$, of them 24 subjects $(80 \%)$ were males \& the remaining 6 subjects $(20 \%)$ were females.

Subsequently, control group and patients group showed substantially significant difference regarding age, BMI, body weight, WC $(\mathrm{p}<0.0001$ for each parameter). Similarly, Comparison between the control group and patients group regarding the laboratory variables showed a statistically significant difference in glucose homeostasis parameters (FBS, 2hpp \& HbA1c \%), insulin resistance parameters (Fasting insulin \& HOMA-IR), the lipid parameters (TC, LDL-c, HDL-c \& TG), EATT and Visfatin $(p<0.0001$ for each parameter) (Table $\mathbf{1}$ ).

It was found that patients group had older age than control group. Comparing BMI and WC among subjects of each group it was significantly higher in patients group in comparison with control group. As regard FBS, 2h.pp, HbA1c, S. Insulin and HOMA it was found significantly higher in patients group than control group. As regard lipid profile: Cholesterol, Triglycerides (TG) and LDL$C$ was found significantly higher in patients group compared to that of control group. In contrast, HDL-C was found lower in patients group compared to that of control group. Epicardial adipose tissue thickness (EATT) was found significantly higher in patients group compared to that of control group. Visfatin was higher in patients group in comparison to control group; it was 16.3 (13.5 - 19.25) and 2.9 $(2.3-3.2)$ respectively (Table $\mathbf{1})$. 
Table (1): Clinical and biochemical characteristics of the study population by the presence of CAD

\begin{tabular}{|c|c|c|c|}
\hline \multirow{2}{*}{ Variables Groups } & $\begin{array}{c}\text { Patients group } \\
(\text { No. = 60) }\end{array}$ & $\begin{array}{c}\text { Control group } \\
(\text { No. = 30) }\end{array}$ & \multirow{2}{*}{ P-value } \\
\hline & $\begin{array}{c}\text { Mean } \pm \text { SD/ } \\
\text { Median(IQR) }\end{array}$ & $\begin{array}{c}\text { Mean } \pm \text { SD/ } \\
\text { Median(IQR) }\end{array}$ & \\
\hline Age (years) & $53.75 \pm 6.04$ & $48.53 \pm 5.02$ & $<0.001$ \\
\hline Weight $(\mathrm{kg})$ & $93.43 \pm 10.02$ & $82.50 \pm 5.68$ & $<0.001$ \\
\hline Height (m) & $1.72 \pm 0.04$ & $1.76 \pm 0.04$ & $<0.001$ \\
\hline BMI (\%) & $31.47 \pm 3.54$ & $26.44 \pm 2.07$ & $<0.001$ \\
\hline $\mathrm{WC}(\mathrm{cm})$ & $97.62 \pm 5.97$ & $87.60 \pm 4.41$ & $<0.001$ \\
\hline SBP & $138.75 \pm 13.77$ & $120.67 \pm 9.71$ & $<0.001$ \\
\hline DBP & $90.58 \pm 10.54$ & $79.50 \pm 7.35$ & $<0.001$ \\
\hline FBS (mg/dl) & $109.88 \pm 27.49$ & $75.00 \pm 4.77$ & $<0.001$ \\
\hline 2h.PP (mg/dl) & $172(135.5-233.5)$ & $128.5(123-137)$ & $<0.001$ \\
\hline HbA1c (\%) & $7.03 \pm 1.47$ & $5.32 \pm 0.20$ & $<0.001$ \\
\hline S.Insulin (uIU/ml) & $14.92 \pm 1.89$ & $10.20 \pm 2.43$ & $<0.001$ \\
\hline HOMA $(\%)$ & $3.4(3-5.1)$ & $1.75(1.5-2.1)$ & $<0.001$ \\
\hline HDL-C (mg/dl) & $44.03 \pm 9.17$ & $49.80 \pm 7.75$ & 0.004 \\
\hline LDL-C (mg/dl) & $189.93 \pm 37.48$ & $103.97 \pm 26.21$ & $<0.001$ \\
\hline $\mathrm{TG}(\mathrm{mg} / \mathrm{dl})$ & $170(135-200)$ & $95(85-105)$ & $<0.001$ \\
\hline CHOL (mg/dl) & $268.65 \pm 42.90$ & $175.17 \pm 26.53$ & $<0.001$ \\
\hline EATT $(\mathrm{mm})$ & $8.83 \pm 1.63$ & $3.51 \pm 0.46$ & $<0.001$ \\
\hline VISFATIN (ng/ml) & $16.3(13.5-19.25)$ & $2.9(2.3-3.2)$ & $<0.001$ \\
\hline \multicolumn{4}{|c|}{$\begin{array}{l}\text { Abbreviations; CAD=coronary artery disease, } \mathrm{BMI}=\text { body mass index, } \mathrm{WC}=\text { waist } \\
\text { circumference, } \mathrm{SBP}=\text { systolic blood pressure, } \mathrm{DBP}=\text { diastolic blood pressure, } \mathrm{FPG}= \\
\text { fasting plasma glucose, } 2 \mathrm{hpp}=\text { two hours post-prandial blood glucose, HbA1C= } \\
\text { glycosylated hemoglobin, HOMA-IR= homeostatic model assessment of insulin } \\
\text { resistance, TG= triglyceride, TC= total cholesterol, LDL= low density lipoprotein, } \\
\text { HDL= high density lipoprotein, EATT= epicardial adipose tissue thickness. }\end{array}$} \\
\hline
\end{tabular}

The severity of CAD was assessed using coronary angiography by estimation the number of vessels affected and according CAD patients was subclassified according to number of diseased coronary arteries into 1 vessel (24 patients), 2 vessels (21 patients) and 3 vessels (15 patients) group (Table 2).

It was found that weight, height, BMI, systolic and diastolic blood pressure, WC, S. Insulin, HOMA, Cholesterol, LDL-C, TG and EATT were significantly higher in groups with more vessels involvement. On other hand there is no statistically difference as regard age, sex, FBS, 2hpp, $\mathrm{HbA} 1 \mathrm{C}$ in relation to number of diseased coronary arteries. It was clear that the serum level of visfatin was significantly higher in groups with more vessels involvement. As the Mean \pm SD of visfatin in one vessel group was $13.13 \pm$ 2.77 and was $16.95 \pm 2.89$ and $21.99 \pm$ 3.91 in two vessels and three vessels respectively (Table 2 ). 
Table (2): Clinical and biochemical characteristics of the study population by the number of affected coronary artery

\begin{tabular}{|c|c|c|c|c|}
\hline \multirow{2}{*}{$\begin{array}{r}\text { Number of } \\
\text { Vessels }\end{array}$} & $\begin{array}{c}1 \text { vessel CAD } \\
(\text { No. }=24)\end{array}$ & $\begin{array}{c}2 \text { vessels CAD } \\
(\text { No. }=21)\end{array}$ & $\begin{array}{c}3 \text { vessels CAD } \\
(\text { No. }=15)\end{array}$ & \multirow{2}{*}{ P-value } \\
\hline & $\begin{array}{c}\text { Mean } \pm \text { SD/ } \\
\text { Median(IOR) }\end{array}$ & $\begin{array}{c}\text { Mean } \pm \text { SD/ } \\
\text { Median(IOR) }\end{array}$ & $\begin{array}{c}\text { Mean } \pm \text { SD/ } \\
\text { Median(IOR) }\end{array}$ & \\
\hline Age (years) & $52.96 \pm 7.10$ & $53.90 \pm 5.13$ & $54.80 \pm 5.56$ & 0.652 \\
\hline Weight $(\mathrm{kg})$ & $89.00 \pm 6.87$ & $92.14 \pm 7.80$ & $102.33 \pm 11.73$ & $<0.001$ \\
\hline Height (m) & $1.73 \pm 0.04$ & $1.72 \pm 0.03$ & $1.70 \pm 0.03$ & 0.036 \\
\hline BMI (\%) & $29.53 \pm 2.25$ & $31.04 \pm 2.33$ & $35.17 \pm 3.90$ & $<0.001$ \\
\hline SBP & $131.88 \pm 12.58$ & $137.14 \pm 10.56$ & $152.00 \pm 10.32$ & $<0.001$ \\
\hline DBP & $85.63 \pm 10.25$ & $90.00 \pm 9.49$ & $99.33 \pm 6.51$ & $<0.001$ \\
\hline $\mathrm{WC}(\mathrm{cm})$ & $94.92 \pm 5.12$ & $97.38 \pm 3.43$ & $102.27 \pm 7.41$ & $<0.001$ \\
\hline FBS (mg/dl) & $105.54 \pm 24.51$ & $108.95 \pm 27.09$ & $118.13 \pm 32.29$ & 0.379 \\
\hline 2h.PP (mg/dl) & $165.5(137-212)$ & $157(134-248)$ & $173(147-273)$ & 0.293 \\
\hline HbA1c (\%) & $6.73 \pm 1.12$ & $7.05 \pm 1.51$ & $7.49 \pm 1.84$ & 0.286 \\
\hline S.Insulin (uIU/ml) & $14.38 \pm 2.24$ & $14.62 \pm 1.36$ & $16.20 \pm 1.32$ & 0.007 \\
\hline HOMA (\%) & $3.4(3-4.3)$ & $3.1(2.8-5.1)$ & $4.2(3.3-6.4)$ & 0.039 \\
\hline CHOL (mg/dl) & $255.13 \pm 44.35$ & $258.71 \pm 36.11$ & $304.20 \pm 29.06$ & $<0.001$ \\
\hline HDL-C (mg/dl) & $43.75 \pm 8.25$ & $40.76 \pm 9.27$ & $49.07 \pm 8.74$ & 0.024 \\
\hline LDL-C (mg/dl) & $180.17 \pm 40.49$ & $183.86 \pm 36.13$ & $214.07 \pm 22.77$ & 0.013 \\
\hline TG (mg/dl) & $160(122.5-187.5)$ & $170(120-185)$ & $210(167-240)$ & 0.028 \\
\hline EAT $(\mathrm{mm})$ & $7.75 \pm 1.66$ & $9.02 \pm 0.93$ & $10.28 \pm 1.08$ & $<0.001$ \\
\hline $\begin{array}{c}\text { VISFATIN } \\
(\mathrm{ng} / \mathrm{ml})\end{array}$ & $13.13 \pm 2.77$ & $16.95 \pm 2.89$ & $21.99 \pm 3.91$ & $<0.001$ \\
\hline
\end{tabular}

Abbreviations; $\mathrm{CAD}=$ coronary artery disease, $\mathrm{BMI}=$ body mass index, $\mathrm{WC}=$ waist circumference, $\mathrm{SBP}=$ systolic blood pressure, $\mathrm{DBP}=$ diastolic blood pressure, $\mathrm{FPG}=$ fasting plasma glucose, $2 \mathrm{hpp}=$ two hours post-prandial blood glucose, HbA1C= glycosylated hemoglobin, HOMA-IR= homeostatic model assessment of insulin resistance, $\mathrm{TG}=$ triglyceride, $\mathrm{TC}=$ total cholesterol, $\mathrm{LDL}=$ low density lipoprotein, HDL $=$ high density lipoprotein, EATT $=$ epicardial adipose tissue thickness.

Visfatin was positively correlated with EATT, Number of coronary vessels affected, Age, BMI, WC, FBS, 2h. pp,
HbA1c, S. Insulin, HOMA, Cholesterol, LDL-C and TG. No association was found for HDL-C (Table 3 and Figures 1\& 2). 
Table (3): The correlation between visfatin and all studied parameters

\begin{tabular}{|c|c|c|}
\hline $\begin{array}{ll}\text { Parameters } & \text { VISFATIN (ng/ml) } \\
\end{array}$ & $\mathbf{r}$ & P-value \\
\hline EATT $(\mathrm{mm})$ & $0.849^{* * *}$ & $<0.001$ \\
\hline Number of Vessel & $0.747^{* *}$ & $<0.001$ \\
\hline Age (years) & $\mathbf{0 . 3 8 8}^{* * *}$ & $<0.002$ \\
\hline BMI (\%) & $0.787^{* *}$ & $<0.001$ \\
\hline $\mathrm{WC}(\mathrm{cm})$ & $0.655^{* * *}$ & $<0.001$ \\
\hline FBS (mg/dl) & $0.644^{* *}$ & $<0.001$ \\
\hline 2h.PP (mg/dl) & $0.637^{\text {** }}$ & $<0.001$ \\
\hline $\mathrm{HbA1c}(\%)$ & 0.638 $^{\text {*** }}$ & $<0.001$ \\
\hline S.Insulin (uIU/ml) & $0^{0.373} 3^{* *}$ & 0.003 \\
\hline $\operatorname{HOMA}(\%)$ & 0.696 *** & $<0.001$ \\
\hline CHOL (mg/dl) & $0.440^{* * *}$ & $<0.001$ \\
\hline HDL-C (mg/dl) & 0.194 & 0.137 \\
\hline LDL-C (mg/dl) & $\mathbf{0 . 3 2 3}^{*}$ & $<0.012$ \\
\hline $\mathrm{TG}(\mathrm{mg} / \mathrm{dl})$ & $\mathbf{0 . 3 9 3}^{* *}$ & $<0.002$ \\
\hline
\end{tabular}

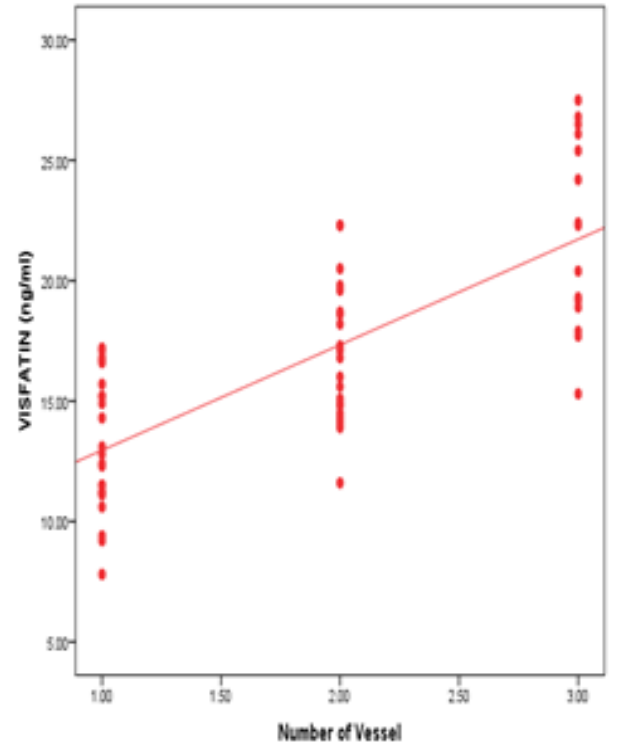

Figure (1): Correlation between visfatin and BMI.

Patients with $\mathrm{CAD}$ were divided to diabetic patients with coronary artery disease: included 30 patients with CAD and diabetes. Their ages ranged between 41 to70 years with a Mean \pm SD of $(56.17$ $\pm 6.63)$, of them 21 subjects $(70 \%)$ were males \& the remaining 9 subjects $(30 \%)$ were females .Non diabetic patients with coronary artery disease: included 30

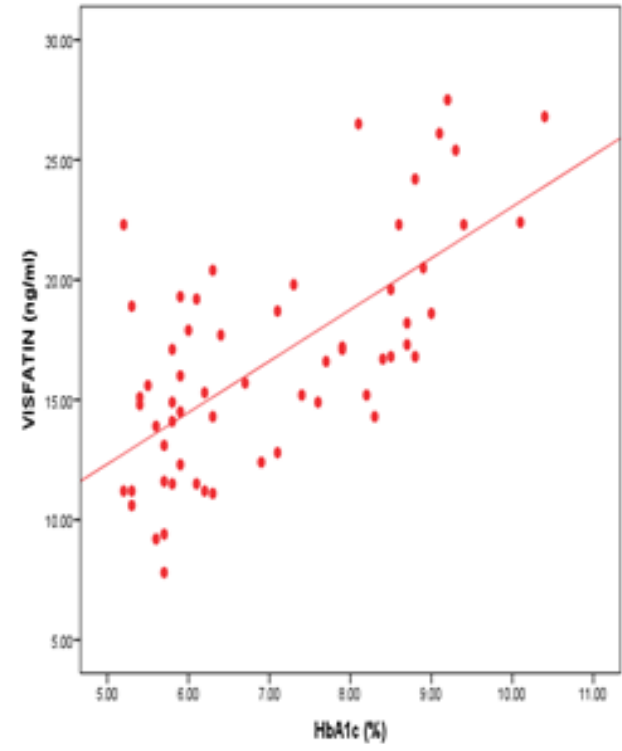

Figure (2): Correlation between visfatin and $\mathrm{HbAlc}$.

patients with CAD and not diabetics. Their ages ranged between 43 to 59 years with a Mean \pm SD of $(51.33 \pm 4.25)$, of them 19 subjects $(63.3 \%)$ were males \& the remaining 11 subjects $(36.7 \%)$ were females. Comparing age, BMI, WC, FBS, 2hpp, HbA1c, HOMA, EATT and visfatin among subjects of each group it was significantly higher in Diabetics with 
coronary artery disease than in Nondiabetics with coronary artery. There was no statistical difference detected between two groups regarding their sex distribution, systolic and diastolic blood pressure, S.Insulin, cholesterol, LDL-C, HDL-C and TG (Table 4).

Table (4): Clinical and biochemical characteristics of the diabetic and non diabetic patients with CAD

\begin{tabular}{|c|c|c|c|}
\hline \multirow{2}{*}{ Variables } & $\begin{array}{l}\text { Diabetic patients with coronary } \\
\text { artery disease }(\text { No. }=\mathbf{3 0})\end{array}$ & $\begin{array}{c}\text { Non diabetic patients with } \\
\text { coronary artery disease (No. }=30)\end{array}$ & \multirow{2}{*}{ P-value } \\
\hline & Mean \pm SD/Median(IQR) & Mean \pm SD/Median(IQR) & \\
\hline Age (years) & $56.17 \pm 6.63$ & $51.33 \pm 4.25$ & $<0.001$ \\
\hline Weight $(\mathrm{kg})$ & $97.83 \pm 10.81$ & $89.03 \pm 6.88$ & $<0.001$ \\
\hline Height (m) & $1.73 \pm 0.04$ & $1.72 \pm 0.03$ & 0.231 \\
\hline $\mathrm{BMI}(\%)$ & $32.73 \pm 4.07$ & $30.20 \pm 2.35$ & 0.003 \\
\hline SBP & $140.33 \pm 13.83$ & $137.17 \pm 13.75$ & 0.308 \\
\hline DBP & $91.83 \pm 10.13$ & $89.363 \pm 10.96$ & 0.363 \\
\hline $\mathrm{WC}(\mathrm{cm})$ & $100.37 \pm 5.92$ & $94.87 \pm 4.68$ & $<0.001$ \\
\hline S.Insulin (uIU/ml) & $14.87 \pm 2.08$ & $14.97 \pm 1.71$ & 0.821 \\
\hline HOMA $(\%)$ & $4.92 \pm 1.09$ & $3.08 \pm 0.34$ & $<0.001$ \\
\hline CHOL (mg/dl) & $268.67 \pm 49.95$ & $268.63 \pm 35.34$ & 0.998 \\
\hline HDL-C (mg/dl) & $43.53 \pm 9.36$ & $44.53 \pm 9.10$ & 0.676 \\
\hline LDL-C (mg/dl) & $190.63 \pm 43.32$ & $189.23 \pm 31.31$ & 0.886 \\
\hline $\mathrm{TG}(\mathrm{mg} / \mathrm{dl})$ & $177.5(125-220)$ & $162.5(140-190)$ & 0.459 \\
\hline EAT (mm) & $9.42 \pm 1.67$ & $8.24 \pm 1.38$ & $<0.002$ \\
\hline VISFATIN (ng/ml) & $18.97 \pm 4.54$ & $14.39 \pm 3.59$ & $<0.001$ \\
\hline \multicolumn{4}{|c|}{$\begin{array}{l}\text { Abbreviations; CAD=coronary artery disease, BMI=body mass index, WC= waist circumference, } \\
\text { SBP=systolic blood pressure, DBP=diastolic blood pressure, HOMA-IR= homeostatic model assessment of } \\
\text { insulin resistance, TG= triglyceride,TC = total cholesterol, } \mathrm{LDL}=\text { low density lipoprotein, HDL= high density } \\
\text { lipoprotein , EATT = epicardial adipose tissue thickness. }\end{array}$} \\
\hline
\end{tabular}

Receiver operating characteristics curve (ROC curve) of visfatin as predictor between Non- diabetic and Diabetic: ROC curve has been drawn to show the cutoff point of visfatin level as predictor between non- diabetic and diabetic groups to diagnose CAD also to show the diagnostic accuracy, sensitivity \&Specificity of such cutoff point for CAD (Figure 3). 


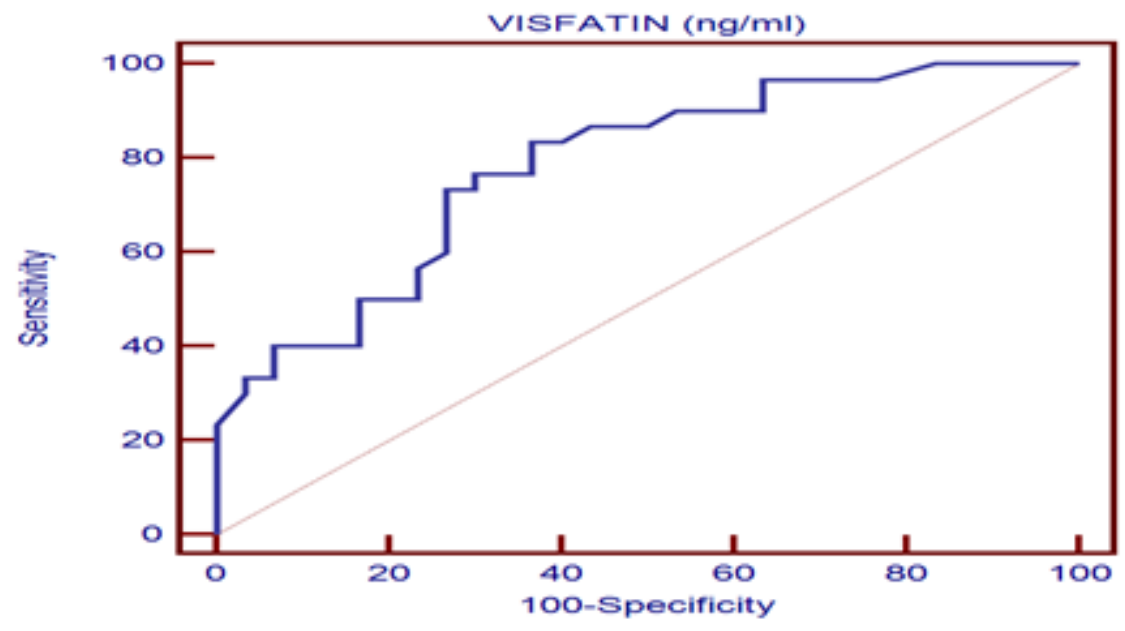

Figure (3): ROC curve of VISFATIN as predictor between Non- diabetic and diabetic patients.

It was found that visfatin cut off level $>15.1 \mathrm{pg} / \mathrm{ml}$ is sensitive by $83.33 \%$ and specific by $63.33 \%$ for predication of
CAD between non - diabetic and diabetic patients (Table 5).

Table (5): Sensitivity, specificity and cutoff value of visfatin in prediction of CAD among diabetic and non-diabetic group

\begin{tabular}{|c|c|c|c|c|c|c|}
\hline Parameter & AUC & Cut of Point & Sensitivity & Specificity & PPV & NPV \\
\hline VISFATIN & 0.783 & $>15.1$ & 83.33 & 63.33 & 69.4 & 79.2 \\
\hline AUC & &
\end{tabular}

$\mathbf{A U C}=$ area under curve, $\mathbf{P P V}=$ positive predictive value, $\mathbf{N P V}=$ negative predictive value.

\section{DISCUSSION}

The evidence obtained in the current study showed increased visfatin serum level in patients with CAD in comparison with normal coronary arteries patients. Serum level of visfatin was significantly higher in groups with more vessels involvement.

Our study showed a significant association between visfatin and EATT, number of coronary vessels affected, Age, BMI, WC, FBS, 2h.pp, HbA1c, S.Insulin, HOMA, Cholesterol, LDL-C and TG. No association was found for HDL-C. These findings suggested that the assessment of visfatin plasma levels can help to identify subjects with many metabolic abnormalities, which result in an increased cardiovascular disease risk.

Our results were concomitant with previous studies. For instance, Duman et al. (2019) notified that serum visfatin level was correlated with the extent and severity of CAD. In this concern, the study of Fadaei et al. (2016) demonstrated that serum levels of visfatin and its mRNA expression were significantly increased in CAD patients, and closely associated with the disease severity. 
Moreover, these results were also in conformity with El-Deek et al. (2014) who showed that patients with stable CAD had increased visfatin levels compared with normal coronary arteries patients. Also, there was a positive correlation between serum visfatin levels and CAD severity as expressed by number of significantly narrowed coronary arteries. Also, the study of Saddi-Rosa et al. (2013) confirmed that circulating visfatin levels are associated with CAD in type 2 diabetic patients.

The study of Mazaherioun et al. (2012) demonstrated that high levels in patients with acute myocardial infarction and had a sensitivity of $70 \%$ and a specificity of $75 \%$ for predicting acute myocardial infarction. They concluded that visfatin plays a role in the development of atherosclerosis as well as destabilization of the plaque.

Kadoglou et al. (2011) studied the serum levels of both vaspin and visfatin in patients with CAD. They found that serum visfatin was significantly related to $C A D$ existence, but not with angiographical indexes of coronary atherosclerosis severity.

In contrast with our study, Choi et al. (2008) study was demonstrated the absence of relationship between plasma visfatin and angiographically confirmed CAD. A nonspecific small patient group might have affected the outcome of this study.

Although the exact mechanism of the pathogenic association of visfatin with CAD cannot be explained on the basis of the present study, several possibilities should be considered. The previous studies demonstrate that visfatin induces secretion of inflammatory cytokines such as IL-6, IL-1 $\beta$, and TNF- $\alpha$, suggesting inflammatory effects of visfatin (Scotece et al., 2012), Visfatin could also increase the expression of metal matrix proteinase (MMP)-8 in macrophages, promote collagen degradation and the plaques vulnerability index ( $\mathrm{Li}$ et al., 2016). Visfatin was indicated to be abundant in foam cells within unstable atherosclerotic plaques (Chiu et al., 2012). Based on these reports, visfatin, a detrimental adipokine, might be involved in the development of atherosclerosis mediated via inflammation.

Our study showed a significant association between visfatin and EATT, Number of vessels, Age, BMI, WC, FBS, 2h.pp, HbA1c, S.Insulin, HOMA, Cholesterol, LDL-C and TG. No association was found for HDL-C. These findings suggested that the assessment of visfatin plasma levels can help to identify subjects with many metabolic abnormalities, which result in an increased cardiovascular disease risk.

Our result was in conformity with previous studies. Filippatos et al. (2013) observed a positive association between visfatin with waist circumference and blood pressure, as well as with total cholesterol and triglyceride levels. Also, Uslu et al. (2012) found increased visfatin levels in T2DM patients. In addition, visfatin levels were positively correlated with HOMA-IR and insulin levels in T2DM patients, and visfatin levels were positively correlated with markers of lipid metabolism such as TC, TG and LDL-C. In a meta-analysis Chang et al. (2011) suggested that the use of visfatin may predict obesity, diabetes status, insulin 
resistance, metabolic syndrome and cardiovascular disease.

Visfatin was significantly higher in Diabetic patients with coronary artery disease. El-Mesallamy et al. (2011) provided several explanations for the increased visfatin levels noted in patients with T2DM. Firstly, increased visfatin levels in diabetic patients may be due to impaired visfatin signaling in target tissues. Secondly, due to the insulin mimetic effects, increased plasma visfatin levels could be a compensatory mechanism in response to hyperglycemia that ameliorates the functional consequences of insulin deficiency or resistance. Thirdly, visfatin-mediated NAD biosynthesis that regulates glucosestimulated insulin secretion may explain increased levels of visfatin in T2DM patients as a compensatory mechanism for $\beta$-cell functioning. Finally, because of the pro-inflammatory properties, these elevated levels could be attributed to the chronic low-grade inflammation present in T2DM.

\section{CONCLUSION}

Patients with established CAD showed increased visfatin serum levels particularly diabetics. Moreover, high visfatin levels were significantly correlated with CAD severity suggesting a link between atherosclerosis and adiposity. There is positive correlation between visfatin and cardiometabolic risk factors such as age, central obesity, and diabetes, lipid profile.

\section{REFERENCES}

1. Bluher M (2019): Obesity: global epidemiology and pathogenesis. Nat Rev Endocrinal, 15, 288-298.
2. Bornachea O, Vea A and Llorente-Cortes $\mathbf{V}$ (2018): Interplay between epicardial adipose tissue, metabolic and cardiovascular diseases. Clin. Investig. Arterioscler, 30, 230-239.

3. Carbone F, Mach $F$ and Montecucco $F$ (2015): The role of adipocytokines in atherogenesis and atheroprogression. Curr Drug Targets, 16(4):295-320.

4. Chang YH, Chang DM, Lin KC, Shin SJ and Lee YJ (2011): Visfatin in overweight/obesity, type 2 diabetes mellitus, insulin resistance, metabolic syndrome and cardiovascular diseases: a meta-analysis and systemic review. Diabetes Metab Res Rev. 27: 515-527.

5. Chiu CA, Yu TH, Hung WC, Lu LF, Chung FM, Tsai IT, Yang CY, Hsu CC, Lu YC and Houng JY (2012): Increased expression of visfatin in monocytes and macrophages in male acute myocardial infarction patients. Mediat Inflamm. 2012:469852.

6. Choi KM, Lee JS, Kim EJ, Baik SH, Seo HS, Choi DS, Oh DJ and Park CG (2008): Implication of lipocalin-2 and visfatin levels in patients with coronary heart disease. Eur J Endocrinol.158 (2), 203-7.

7. Duman H, Özyıldız AG, Bahçeci İ, Duman H, Uslu A and Ergül E (2019): Serum visfatin level is associated with complexity of coronary artery disease in patients with stable angina pectoris. Ther Adv Cardiovasc Dis.13:1753944719880448.

8. El-Deek SEM, Abdelmegid MAF, Soliman MM and Youssef AA (2014): Relation of Vaspin and Visfatin Levels with the Presence and the Severity of Coronary Artery Disease. Universal Journal of Medical Science.2 (4): 4350.

9. El-Mesallamy HO, Kassem DH, ElDemerdash E and Amin AI (2011): Vaspin and visfatin/Nampt are interesting interrelated adipokines playing a role in the pathogenesis of type 2 diabetes mellitus. Metabolism, 60: 6370.

10. Fadaei R, Parvaz E and Emamgholipour $S$ (2016): The mRNA Expression and Circulating Levels of Visfatin and Their Correlation with Coronary Artery Disease Severity and 25- 
Hydroxyvitamin D. Horm Metab Res. 48(4):269-274.

11. Filippatos TD, Tsimihodimos V, Derdemezis CS, Gazi IF, Saougos V, Mikhailidis DP, Tselepis AD and Elisaf MS (2013): Increased plasma visfatin concentration is a marker of an atherogenic metabolic profile. Nutr Metab Cardiovasc Dis.23 (4), 330-6.

12. Kadoglou NP, Gkontopoulos A, Kapelouzou A, Fotiadis G, Theofilogiannakos EK, Kottas G and Lampropoulos S (2011): Serum levels of vaspin and visfatin in patients with coronary artery disease-Kozani study. Clin Chim Acta, 412(1-2):48-52.

13. Li B, Zhao Y, Liu H, Meng B, Wang J, Qi T, Zhang H, Li T, Zhao $P$ and Sun $H$ (2016): Visfatin destabilizes atherosclerotic plaques in Apolipoprotein E-deficient mice. PLoS One, 11(2):e0148273.

14. Mazaherioun M, Hosseinzadeh-Attar MJ and Janani L (2012): Elevated serum visfatin levels in patients with acute myocardial infarction. Arch Iran Med.15 (11):688-692.

15.Saddi-Rosa P, Viana de Oliveira CS, Crispim F, Giuffrida FM, de Lima VC, Vieira JG, Doria A, Velho $G$ and Reis AF (2013): Association of circulating levels of nicotinamide phosphoribosyl transferase (NAMPT/Visfatin) and of a frequent polymorphism in the promoter of the NAMPT gene with coronary artery disease in diabetic and non-diabetic subjects. Cardiovasc Diabetol. 12(1): 119

16. Scotece M, Conde J and Gomez R (2012): Role of adipokines in atherosclerosis: interferences with cardiovascular complications in rheumatic diseases. Mediators of Inflammation, Article ID 125458.

17. Ucgun $T$, Başar $C$ and Memişoğ ulları $R$ (2014): Serum visfatin and omentin levels in slow coronary flow. Rev Port Cardiol. 33: 789794.

18. Uslu S, Kebapci N and Karaetal M (2012): Relationship between adipocytokines and cardiovascular risk factors in patients with type 2 diabetes mellitus. Experimental and Therapeutic Medicine, 4 (1): 113-120.

19. Villasante Fricke AC, Iacobellis G (2019): Epicardial Adipose Tissue: Clinical Biomarker of Cardio-Metabolic Risk. Int J Mol Sci, 20(23):5989.

20. Wang P, Vanhoutte PM, Miao CY (2012): Visfatin and cardio-cerebro-vascular disease. J Cardiovasc Pharmacols, 59(1):1-9.

21.Zheng, L., Xu, X., Wan, $R$ (2019): Association between serum visfatin levels and atherosclerotic plaque in patients with type 2 diabetes. Diabetol Metab Syndr. 11: 60-67. 
مستوى الفسفاتين بالدم و علاقته بشدة امر اض الثريان التاجى أيمن محمد سالم*, عبداللاه حسين الصادق*, محمد نصحى الألفى*, منصور محمد لطفى**; كامل سليمان حماد*** لطن

أقسام الأمر اض الباطنة** والقلب** و الباثولوجيا الإكلينيكية****، كلية الطب، جامعة الأزهر

E-mail: ayman.nafie@yahoo.com

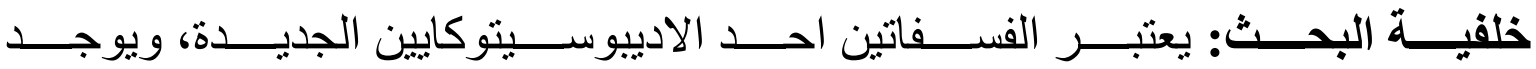

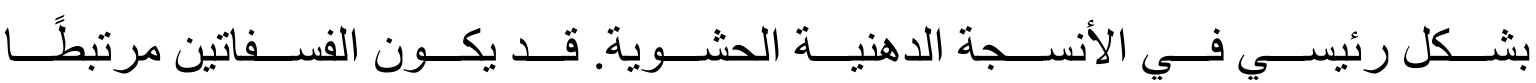

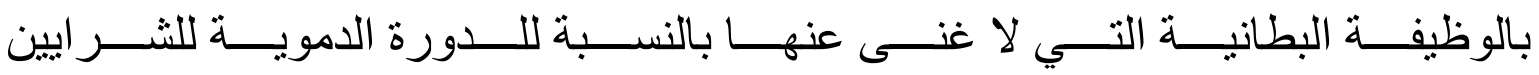
التاجية، وقد يكون مؤشرًا على حدوث إلتهابات بالثر ايين التاجية.

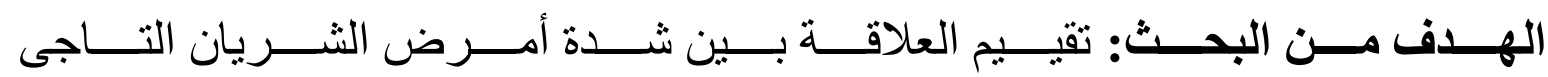

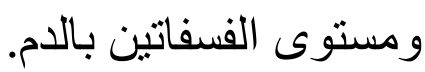

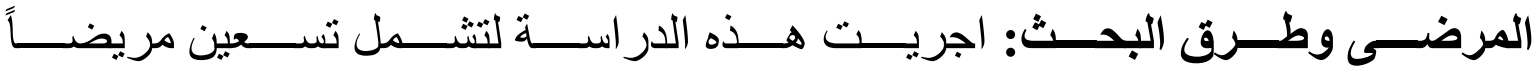

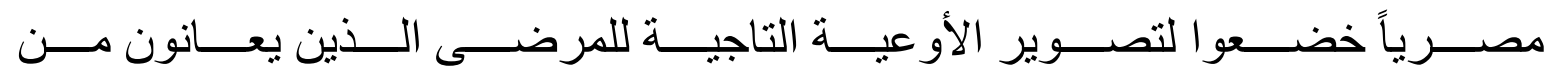

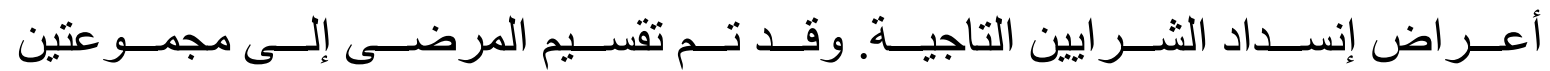

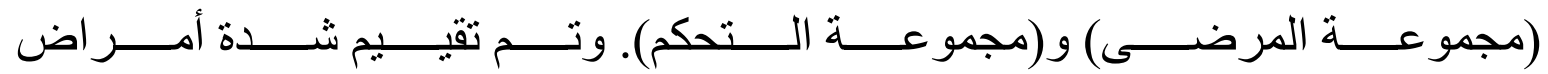

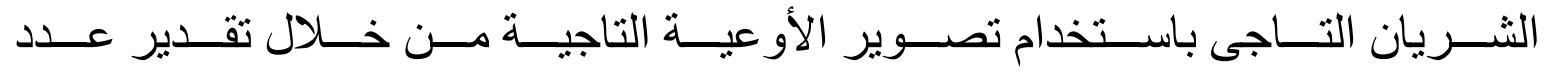

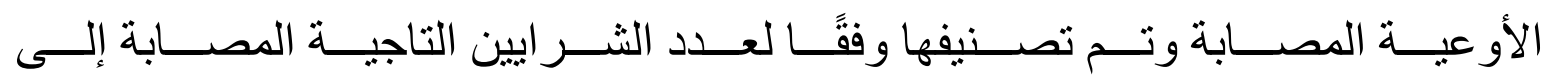

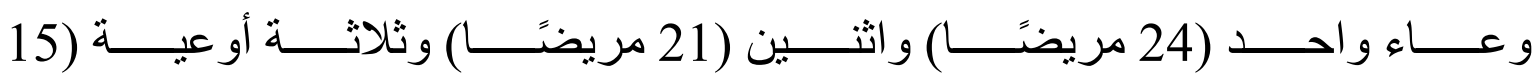

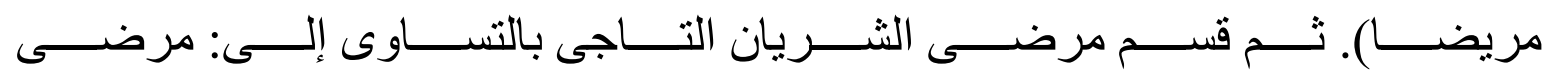

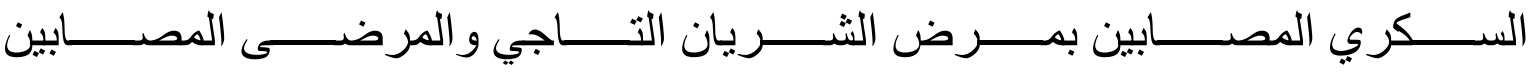
بمرض الثريان التاجي و لا يعانون من السكرى.

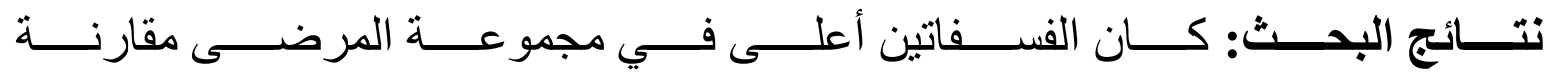

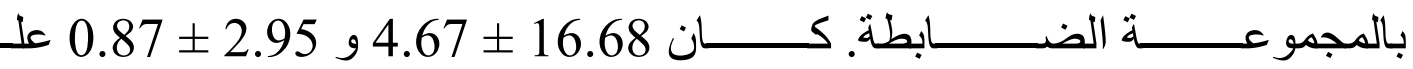




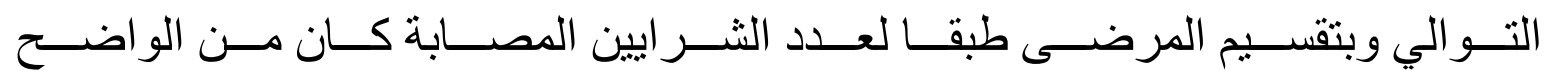

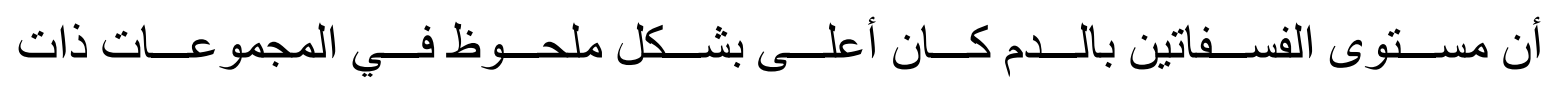

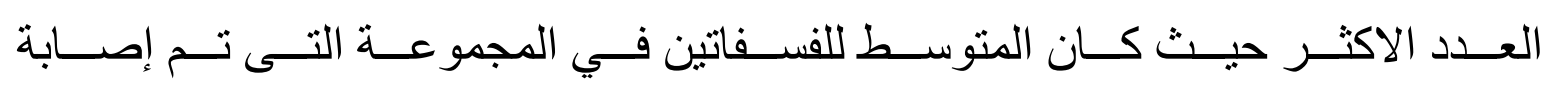

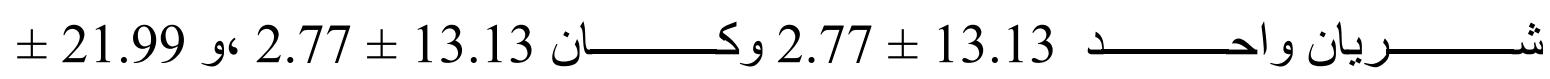
3.91 في عدد اثنين وثلاثة شر ايين على التو الي.

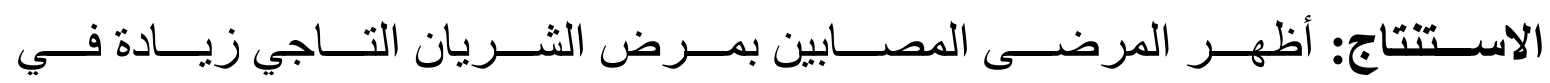

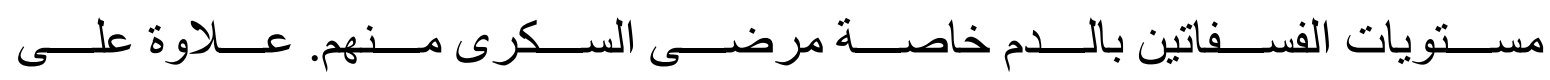

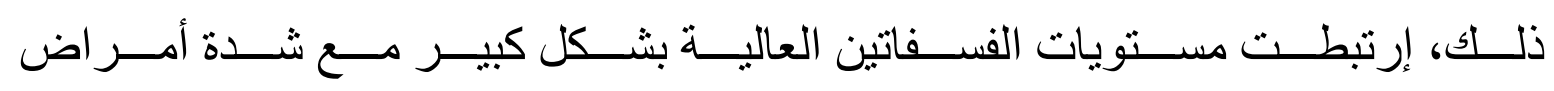

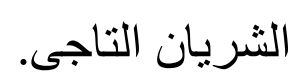
الكلمات الدالة : الفسفاتين - أمر اض الثريان التاجى . 